\title{
Katarzyna Przybyla
}

Wrocław University of Environmental and Life Sciences

e-mail: katarzyna.przybyla@upwr.edu.pl

\section{STRUCTURAL TRANSFORMATIONS \\ OF ECONOMIC FUNCTIONS OF WARSAW}

\section{PRZEKSZTALCENIA STRUKTURALNE FUNKCJI EKONOMICZNYCH WARSZAWY}

DOI: $10.15611 /$ pn.2017.476.06

JEL Classification: R00

Summary: The purpose of the article is to identify the specialized (exogenous) functions of Polish capital - Warsaw - and to analyze this town functional structure in the period 2004-2014. The discussed period is characterized by the development of country economy, which coincided with the Polish accession to the European Union structures. The conducted research covered the size, structure and changes of employment. The research was conducted at the background of economic base theory with regard to a city using two measures - surplus employee index (SEI) and Florence's index of specialization (FIS). The research can turn out useful in urban development planning and in city management.

Keywords: city functions, methods for assessing functions of settlement units.

Streszczenie: Celem artykułu jest identyfikacja wyspecjalizowanych (egzogenicznych) funkcji stolicy Polski oraz analiza przekształceń struktury funkcjonalnej miasta w latach 2004-2014. Okres ten to czas rozwoju gospodarki kraju, powiązany z akcesją Polski do struktur Unii Europejskiej. Przeprowadzono badania nad wielkością, strukturą i zmianami zatrudnienia. Badanie wykonane zostało na gruncie teorii bazy ekonomicznej miasta, z wykorzystaniem dwóch mierników: wskaźnika nadwyżki pracowników (WNP) i współczynnika specjalizacji Florence'a (WSF). Badanie może być przydatne w planowaniu rozwoju i w zarządzaniu miastem.

Słowa kluczowe: funkcje miasta, metody oceny funkcji jednostek osadniczych.

\section{Introduction}

Mazowieckie region is located in the central-eastern part of Poland. It covers the area of 35,6 thousand $\mathrm{km}^{2}$, which makes up about $11.4 \%$ of the entire country area. It is inhabited, in accordance with 2014 data, by over 5,3 million people, which ranks it as the first in the country in terms of population number. The region capital and 
also the capital of Poland is Warsaw, with 1.7 million inhabitants, covering the area of $517 \mathrm{~km}^{2}$. The city is the seat of both central government and the authorities of Mazowieckie region; it concentrates, along with the surrounding urban areas, the major part of measured GDP, i.e. the country economic potential. The level of GDP per capita in 2013, in Mazowieckie region was PLN 69043 (EUR 15356.2 in line with the average exchange rate of the National Bank of Poland as at 2016-01-26), changing the country average by $60.5 \%$ [Produkt krajowy brutto... 2015]. It is worth noticing that the city borders with the highest rank protected area - Kampinos National Park. Therefore, since 1959 Warsaw has been restrained by the spatial development barrier in north-western direction [Kulczyk-Dynowska 2013]. The main rivers of the region are: Vistula (Wisła), Bug and Wkra. In 2010 a great flood struck the examined region [Piepiora 2012].

In the period covered by the research the city economic base was subject to interesting transformations. The purpose of the article is to identify exogenous functions and to analyze transformations in their functional structure occurring in the period 2004-2014.

\section{Research method}

As it has already been mentioned the conducted study is based on the economic base theory and uses two measures - surplus employee index (SEI) and Florence's index of specialization (FIS).

Equation 1: surplus employee index (SEI)

$$
Z_{\text {egiM }}=Z_{i} M-\left(Z M \cdot \frac{Z_{i} K}{Z K}\right),
$$

where: $Z_{\text {egiM }}-$ level of externally (exogenously) driven employment in sector $i$ within a city,

$Z_{i} M-$ level of employment in sector $i$ within a city,

$Z M$ - overall level of employment within a city,

$Z_{i} K-$ level of employment in sector $i$ within a country (region),

$Z K$ - overall level of employment within a country (region).

Equation 2: Florence's index of specialization (FIS)

$$
W=\frac{\left(Z_{i} M\right) /(Z M)}{\left(Z_{i} K\right) /(Z K)}
$$

where: $W$ - Florence's index of specialization,

$Z_{i} M-$ level of employment in sector $i$ within a city,

$Z M-$ overall level of employment within a city,

$Z_{i} K-$ level of employment in sector $i$ within a country (region),

$Z K$ - overall level of employment within a country (region). 
The level of a city's specialization in a particular sector can be qualitatively described as follows:

$W \leq 1$ - the city does not specialize in a given sector, i.e. this sector is endogenous,

$1<W \leq 1,5$ - the city shows a low level of specialization in a given sector,

$1,5<W \leq 2-$ the city shows a medium level of specialization in a given sector,

$W>2$ - the city shows a high level of specialization in a given sector [Obrębalski 2002].

The methods of economic base theory with regard to a city, used in the article, have already received complex coverage in previous studies [Przybyła, Przybyła 2011, 2014].

The preliminary analysis was conducted in 2004. It results, to a great extent, from the fact that Poland joined the European Union structures in May 2004 - thus, it remains the crucial reference point from the perspective of conducted studies. It was followed by the analysis of transformations in the city functional structures covering the period 2008-2014.

It should be emphasized that the system of data collection, regarding the size of employment in economy, was undergoing changes in the period from 2004 till 2014. The data for 2004 were published in accordance with Polish Statistical Classification of Economic Activities (NACE) 2004, whereas for the years 2008-2014 in line with NACE 2007. These changes result in partial data incomparability, along with occasionally unchanged names of classification levels [Rynek pracy... 2011]. Therefore, taking advantage of expert knowledge turned out indispensable in the carried out research.

\section{Transformations of the city functional structure}

At the beginning it can be observed that the total employment in Warsaw (Tables 1, 3 ) was steadily growing in the period from 2004 till 2014. Warsaw represents the city strongly included in the global economy, hence it was affected by the economic downturn resulting from the global economic crisis. It was reflected in the dynamics slowdown of employment growth.

Based on the data presented in Tables 1 and 3 SEI and FIS were calculated in 2004, 2008 and in 2014 (Tables 2, 4). The structure adopted as the research reference basis was the structure of employment in the country. The form of SEI was also adjusted to the comparable relative format, and thus the measure of particular types of city-forming functions was developed for the Polish capital, i.e. employment structure in an exogenous group (Tables 2, 4).

In 2004 the following sections were of the most significant importance for the part of Warsaw economy playing exogenous functions: Warehousing and support activities for transportation - I, Financial intermediation - $J$ and Real estate, renting and business activities $-\mathrm{K}$. These sections covered the total of $77 \%$ of the cityforming group. Additionally, the medium specialization level was presented by the city with reference to section $\mathrm{H}$ and low for sections: F, G, L, M, O. In 2004 the city represented a multi-functional center with the dominating role of diversified services. 
Table 1. Employment in national economy in accordance with NACE sections 2004 (in thousands)

\begin{tabular}{|l|r|r|}
\hline \multirow{2}{*}{ NACE SECTIONS 2004/ SECTION SYMBOL } & POLAND & WARSAW \\
\cline { 2 - 3 } & \multicolumn{2}{|c|}{2004} \\
\hline Total & 12720.2 & 726.2 \\
\hline Agriculture / A+B & 2145.1 & 1.4 \\
\hline Industry total / C+D+E & 2930.9 & 107.4 \\
\hline Construction / F & 588.8 & 36.5 \\
\hline Wholesale and retail trade; repair of motor vehicles, motorcycles & & \\
and personal and household goods / G & 1983.1 & 124.1 \\
\hline Hotels and restaurants / H & 216.3 & 19.4 \\
\hline Transport, storage and communication / I & 704.8 & 69.3 \\
\hline Financial intermediation / J & 274.7 & 50.8 \\
\hline Real estate, renting and business activities / K & 940.4 & 130.1 \\
\hline Public administration and defense; compulsory social security / L & 851.6 & 58.5 \\
\hline Education / M & 999.5 & 57.2 \\
\hline Health care and social aid / N & 704.5 & 39.9 \\
\hline Other community, social and personal service activities / O & 380.5 & 31.6 \\
\hline
\end{tabular}

Source: [Rocznik Statystyczny... 2005; Rocznik Statystyczny Rzeczypospolitej... 2015, Urząd Statystyczny].

Table 2. Values of SEI (in thousands) and FIS and employment structure indices in the exogenous group for Warsaw

\begin{tabular}{|c|c|c|c|}
\hline \multirow[t]{2}{*}{ NACE 2004 SECTIONS } & FIS & SEI & $\begin{array}{l}\text { Employment } \\
\text { structure } \\
\text { in exogenous } \\
\text { group }\end{array}$ \\
\hline & \multicolumn{3}{|c|}{2004} \\
\hline Agriculture / A+B & 0.01 & -121.12 & $\mathrm{x}$ \\
\hline Industry total $/ \mathrm{C}+\mathrm{D}+\mathrm{E}$ & 0.64 & -59.88 & $\mathrm{x}$ \\
\hline Construction / F & 1.09 & 2.91 & $1.6 \%$ \\
\hline $\begin{array}{l}\text { Wholesale and retail trade; repair of motor vehicles, motorcycles } \\
\text { and personal and household goods / G }\end{array}$ & 1.10 & 10.88 & $6.0 \%$ \\
\hline Hotels and restaurants / H & 1.57 & 7.09 & $3.9 \%$ \\
\hline Transport, storage and communication / I & 1.72 & 29.08 & $16.0 \%$ \\
\hline Financial intermediation / J & 3.24 & 35.07 & $19.3 \%$ \\
\hline Real estate, renting and business activities / $\mathrm{K}$ & 2.42 & 76.37 & $42.1 \%$ \\
\hline Public administration and defense; compulsory social security / L & 1.20 & 9.85 & $5.4 \%$ \\
\hline Education / M & 1.00 & 0.16 & $0.1 \%$ \\
\hline Human health and social aid / $\mathrm{N}$ & 0.99 & -0.33 & $\mathrm{x}$ \\
\hline Other community, social and personal service activities / O & 1.46 & 9.92 & $5.5 \%$ \\
\hline Exogenous group size & - & 181.33 & - \\
\hline
\end{tabular}

Source: author's estimations. 
Table 3. Employment in national economy in accordance with NACE sections 2007 in 2008 and in 2014 (in thousands)

\begin{tabular}{|l|r|r|r|r|}
\hline \multirow{2}{*}{ NACE SECTIONS 2004 / SECTION SYMBOL } & \multicolumn{2}{c|}{ POLAND } & \multicolumn{2}{c|}{ WARSAW } \\
\cline { 2 - 5 } & \multicolumn{1}{|c|}{2008} & \multicolumn{1}{c|}{2014} & \multicolumn{1}{c|}{2008} & \multicolumn{1}{c|}{2014} \\
\hline Total & 14037.2 & 14563.4 & 829.4 & 833.5 \\
\hline Agriculture, hunting and related service activities / A & 2128.3 & 2384.9 & 2.1 & 1.1 \\
\hline Industry total / B+C+D+E & 3061.2 & 2955.7 & 89.9 & 70.9 \\
\hline Construction / F & 877.5 & 820 & 36.7 & 36.1 \\
\hline $\begin{array}{l}\text { Wholesale and retail trade; repair of motor vehicles and } \\
\text { motorcycles / G }\end{array}$ & 2287.2 & 2176.6 & 140.9 & 133.4 \\
\hline Transportation and storage / H & 733.2 & 743.7 & 58.1 & 52.2 \\
\hline Accommodation and food service activities / I & 274.7 & 248.7 & 22.7 & 19.2 \\
\hline Information and communication / J & 233.1 & 292.1 & 65.9 & 61.9 \\
\hline Financial and insurance activities / K & 348 & 356.8 & 75.6 & 88.7 \\
\hline Real estate activities / L & 192.7 & 203.9 & 29.9 & 24.7 \\
\hline Professional, scientific and technical activities / M & 472.6 & 588.7 & 76.2 & 82.0 \\
\hline Administrative and support service activities / N & 374.5 & 464.8 & 45.8 & 47.3 \\
\hline $\begin{array}{l}\text { Public administration and defense; compulsory social } \\
\text { security / O }\end{array}$ & & & & \\
\hline Education / P & 919 & 971.1 & 66.1 & 74.7 \\
\hline Healthcare and social aid / Q & 1058.1 & 1124.2 & 61.0 & 76.8 \\
\hline Arts, entertainment and recreation / R & 728.9 & 827.3 & 37.9 & 44.4 \\
\hline Other / S, T, U & 145.8 & 144.9 & 16.7 & 15.3 \\
\hline
\end{tabular}

Source: [Rocznik Statystyczny Rzeczypospolitej... 2015; Rocznik Statystyczny... 2010; Rocznik Statystyczny Warszawy 2015].

The city was characterized by high level of specialization in terms of NACE $2007 \mathrm{~J}-\mathrm{M}$ sections at the background of the country in the years 2008-2014. At the same time the average scope of this specialization, measured by FIS arithmetic mean for the sections where FIS $>1$, presented a slight decrease in this period (2008 - 2.28, $2011-2.04)$. It should, however, be observed that a significant improvement occurred in this area against 2004 (1.64).

It can be adopted that high and increasing specialization in financial and insurance activities - section K of NACE 2007 - remains the direct continuation of specialization in section J of NACE 2004. Simultaneously, this particular activity presented fundamental city-forming function for Warsaw's economy (in 2014 over 26\% of exogenous group workers were employed in section K). Section M was separated in NACE 2007 system (professional, scientific and technical activities). It covers e.g. the activities related to research, development works or technical testing and analyses. Before, in NACE 2004, these activities were spread between sections B, I, K, N, O. Due to the marginal importance of agricultural sector in Warsaw's economic structure and the absence of specialization referring to Healthcare and social aid, the 
Table 4. SEI values (in thousands) and FIS and employment structure indices in the exogenous group for Warsaw in 2008 and 2014 (NACE 2007)

\begin{tabular}{|l|r|r|r|r|r|r|}
\hline \multirow{2}{*}{$\begin{array}{c}\text { SECTION } \\
\text { SYMBOL }\end{array}$} & \multicolumn{2}{c|}{ FIS } & \multicolumn{2}{c|}{ SEI } & \multicolumn{2}{c|}{$\begin{array}{c}\text { Employment structure } \\
\text { in exogenous group }\end{array}$} \\
\cline { 2 - 7 } & 2008 & 2014 & \multicolumn{1}{|c|}{2008} & \multicolumn{1}{c|}{2014} & \multicolumn{1}{c|}{2008} & \multicolumn{1}{c|}{2014} \\
\hline $\mathrm{A}$ & 0.02 & 0.01 & -123.65 & -135.44 & $\mathrm{x}$ & $\mathrm{x}$ \\
\hline $\mathrm{B}+\mathrm{C}+\mathrm{D}+\mathrm{E}$ & 0.50 & 0.42 & -90.97 & -98.24 & $\mathrm{x}$ & $\mathrm{x}$ \\
\hline $\mathrm{F}$ & 0.71 & 0.77 & -15.15 & -10.81 & $\mathrm{x}$ & $\mathrm{x}$ \\
\hline $\mathrm{G}$ & 1.04 & 1.07 & 5.76 & 8.79 & $2.4 \%$ & $3.4 \%$ \\
\hline $\mathrm{H}$ & 1.34 & 1.23 & 14.78 & 9.59 & $6.0 \%$ & $3.7 \%$ \\
\hline $\mathrm{I}$ & 1.40 & 1.35 & 6.47 & 4.92 & $2.6 \%$ & $1.9 \%$ \\
\hline $\mathrm{J}$ & 4.78 & 3.71 & 52.13 & 45.23 & $21.3 \%$ & $17.6 \%$ \\
\hline $\mathrm{K}$ & 3.68 & 4.35 & 55.04 & 68.31 & $22.5 \%$ & $26.5 \%$ \\
\hline $\mathrm{L}$ & 2.63 & 2.12 & 18.51 & 13.04 & $7.6 \%$ & $5.1 \%$ \\
\hline $\mathrm{M}$ & 2.73 & 2.43 & 48.28 & 48.31 & $19.7 \%$ & $18.8 \%$ \\
\hline $\mathrm{N}$ & 2.07 & 1.78 & 23.67 & 20.68 & $9.7 \%$ & $8.0 \%$ \\
\hline $\mathrm{O}$ & 1.22 & 1.34 & 11.80 & 19.08 & $4.8 \%$ & $7.4 \%$ \\
\hline $\mathrm{P}$ & 0.98 & 1.19 & -1.52 & 12.46 & $\mathrm{x}$ & $4.8 \%$ \\
\hline $\mathrm{Q}$ & 0.88 & 0.94 & -5.17 & -2.91 & $\mathrm{x}$ & $\mathrm{x}$ \\
\hline $\mathrm{R}$ & 1.94 & 1.85 & 8.09 & 7.01 & $3.3 \%$ & $2.7 \%$ \\
\hline $\mathrm{S}, \mathrm{T}, \mathrm{U}$ & 0.33 & 0.33 & -7.96 & -10.03 & $\mathrm{x}$ & $\mathrm{x}$ \\
\hline $\mathrm{Exogenous} \mathrm{group} \mathrm{size}$ & - & - & 244.52 & 257.43 & - & - \\
\hline
\end{tabular}

Source: author's estimations.

specialization within its framework can be considered as the continuation of specializations in sections I, K, O of NACE 2004. The recognized importance of information and communication section should also be emphasized. This section (J) covers production and dissemination of information and cultural goods, ITC or data processing service activities (e.g. programming and broadcasting activities, telecommunications) - in many cases they represent modern activities, having strong impact on the country economy and culture.

The sections of industrial nature did not play any exogenous functions in 2008 and 2014, therefore the trend characteristic for previous years was not reversed. Moreover, construction lost its specialization, which is also the manifestation of a long-lasting tendency towards its decreasing significance for the part of city economy facing outwards. It can be stated that Warsaw remained a service oriented center, presenting a diversified activity structure. 


\section{Conclusions}

Warsaw represented a multi-functional city in the entire period covered by the study, with service sector playing the leading role. According to the dominating approach presented in the subject literature, these settlement units which concentrate several or all types of functions in their area have greater chances of survival and fast development [Dziewoński et al. 1977]. The study illustrated that (at least) up to 2004 the activities related to financial services and science, transport and communication had been of vital importance for the city economy. The common knowledge is that the political and administrative city function decides about the city rank in the settlement network of the country and often also about its developmental opportunities; it is interesting to notice that even though it was significant for Warsaw it did not dominate its economy. Tourism and recreation function was also important for the city-forming. The thought-provoking fact is that the diagnosed status, in terms of the industrial function does not reflect the crucial role played by this function in the period prior to the socio-economic system transformation. It can be concluded that industrial activities are pushed out of the city.

It is worth paying attention to the fact that from 2004 till 2011 the size of exogenous group was steadily increasing in the city. One can assume that this result is the derivative of dynamic developmental processes occurring in the capital, which can be associated with Warsaw's stronger inclusion in the global economy as the result of Polish accession to the European Union structures. Even though the global economic crisis did slow down this process it, however, did not manage to stop it. The suggested approach for the quantification of functions played by a city remains the component of the currently postulated research trend related to taking advantage of parametric assessments in local development management [Foryś 2009; Kazak et al. 2014]. The application of the discussed measures can support the discussionmaking processes about further development of local authorities.

\section{References}

Dziewoński K., Gawryszewski A., Iwanicka-Lyrowa E., Jelonek A., Jerczyński M., Węcławowicz G. 1977, Rozmieszczenie i migracje ludności a system osadniczy Polski Ludowej, Prace Geograficzne IG PAN nr 117

Foryś I., 2009, Wykorzystanie analizy wielowymiarowej do oceny potencjału rozwoju lokalnego rynku nieruchomości mieszkaniowych, Studia i Materiały Towarzystwa Naukowego Nieruchomości, vol. 17 no. 2, Olsztyn, pp. 7-20.

Kazak J., Szewrański Sz., Decewicz P., 2014, Holistic Assessment of Spatial Policies for Sustainable Management: Case Study of Wroclaw Larger Urban Zone (Poland), [in:] Geodesign by Integrating Design and Geospatial Sciences, Geodesign, vol. 111, Springer International Publishing, Cham, Heidelberg, New York, Dordrecht, London, pp. 71-85.

Kulczyk-Dynowska A., 2013, Diversified spatial neighbourhood - a metropolis and a national park, [in:] Regional Economy in Theory and Practice, Research Papers of Wroclaw University of Economics, no. 286, pp. 83-84. 
Obrębalski M., 2002, Przemiany funkcjonalne subregionu jeleniogórskiego w końcu XIX i w XX wieku, Śląski Przegląd Statystyczny, no. 1(7), Wrocław University of Economics Publishing House, Wrocław.

Piepiora Z., 2012, The attempt of the evaluation of the efficiency of counteracting natural disasters' effects in the Masovian Voivodeship (NUTS 2), [in:]: Sborník př́spěvků z mezinárodní vědecké conference. MMK 2012. MEZINÁRODNÍ MASARYKOVA KONFERENCE PRO DOKTORANDY A MLADÉ VĚDECKÉ PRACOVNÍKY, ročník III, Hradec Králové, pp. 12461254.

Produkt krajowy brutto - Rachunki regionalne w 2013 r., 2015, Urząd Statystyczny w Katowicach, Główny Urząd Statystyczny, Katowice, http://stat.gov.pl/obszary-tematyczne/rachunki-narodowe/ rachunki-regionalne/ (access 04.04.2016).

Przybyła Z., Przybyła K., 2011, The transformations in the functional structure of Jelenia Góra, [in:] Hradec Economic Days 2011, Economic Development and Management of Regions, part II, University of Hradec Kralove, Hradec Kralove, pp. 239-244.

Przybyła Z., Przybyła K., 2014, Transformation of the economic base of a town - the case study of Jelenia Góra, [in:] Hradec Economic Days 2014, Economic Development and Management of Regions, part IV, University of Hradec Kralove, Hradec Kralove, pp. 208-214.

Rocznik Statystyczny Rzeczypospolitej Polskiej 2005, 2005, Główny Urząd Statystyczny, Warszawa. Rocznik Statystyczny Rzeczypospolitej Polskiej 2010, 2010, Główny Urząd Statystyczny, Warszawa. Rocznik Statystyczny Rzeczypospolitej Polskiej 2015, 2015, Główny Urząd Statystyczny, Warszawa. Rocznik Statystyczny Warszawy 2015, 2015, Urząd Statystyczny w Warszawie, Warszawa.

Rynek pracy w województwie dolnośląskim w 2010 r., 2011, Urząd Statystyczny we Wrocławiu, Wrocław. 